\title{
Saving the critically injured trauma patient: a retrospective analysis of 1000 uses of intraosseous access
}

\author{
Philippa H Lewis $^{1 *}$, Chris R Wright ${ }^{2}$ \\ From London Trauma Conference 2014 \\ London, UK. 9-12 December 2014
}

\section{Objective}

Intraosseous access (IO) is becoming increasingly accepted in adult populations as an alternative to peripheral vascular access; however there is still insufficient evidence in large patient groups supporting its use.

\section{Methods}

Retrospective review. This paper reports on the use of IO devices over a 7 year period from August 2006 to August 2013 during combat operations in Afghanistan. A database search of the Joint Theatre Trauma Registry (JTTR) was carried out looking for all the incidences of IO access use during this time. Excel ${ }^{\mathrm{TM}}$ (Microsoft) was used to manage the dataset and perform descriptive statistics on the patient demographics, injuries, treatments and complications that were retrieved.

\section{Results}

1014 IO devices were used in 830 adult patients with no major complications. The rate of minor complications, the majority of which were device failure, was $1.38 \%$. 5124 separate infusions of blood products or fluids occurred via IO access, with $36 \%$ being of packed red cells. On average each casualty received 6.95 different infusions of blood products and fluids, and 3.28 separate infusions of drugs through $\mathrm{IO}$ access. 32 different drugs were infused to 367 patients via IO, the most frequent being anaesthetic agents. IO access was used in the prehospital environment, during tactical helicopter evacuation and within hospitals.

* Correspondence: DPHCLSE-HYD-GDMO-01@mod.uk

${ }^{1}$ Royal Army Medical Corps, 4 Armoured Medical Regiment, Aldershot, UK Full list of author information is available at the end of the article

\section{Conclusion}

IO access can be used to administer a wide variety of life saving medications quickly, easily and with low complication rates. This highlights its valuable role as an alternative method of obtaining vascular access, vital when resuscitating the critically injured trauma patient.

\section{Authors' details \\ ${ }^{1}$ Royal Army Medical Corps, 4 Armoured Medical Regiment, Aldershot, UK. ${ }^{2}$ Emergency Department, Imperial College NHS Foundation Trust, London,} UK.

Published: 11 September 2015

doi:10.1186/1757-7241-23-S2-A15

Cite this article as: Lewis and Wright: Saving the critically injured trauma patient: a retrospective analysis of 1000 uses of intraosseous access. Scandinavian Journal of Trauma, Resuscitation and Emergency Medicine 2015 23(Suppl 2):A15.

Submit your next manuscript to BioMed Central and take full advantage of:

- Convenient online submission

- Thorough peer review

- No space constraints or color figure charges

- Immediate publication on acceptance

- Inclusion in PubMed, CAS, Scopus and Google Scholar

- Research which is freely available for redistribution

Submit your manuscript at www.biomedcentral.com/submit
() Biomed Central 